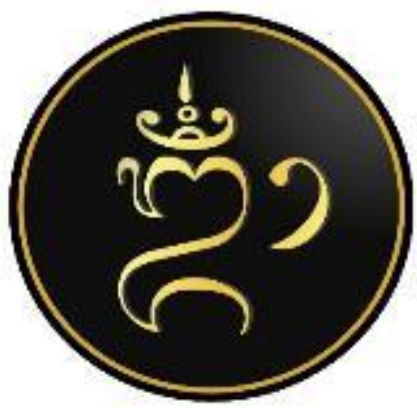

E-ISSN: $2722-8576$

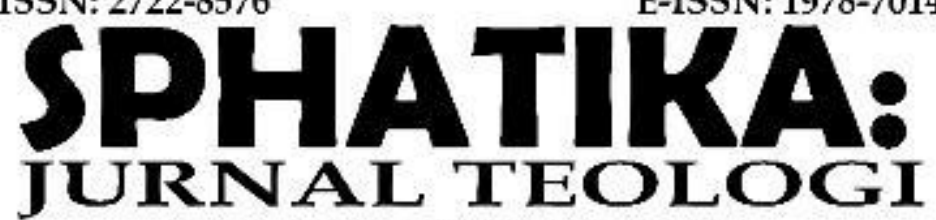

UNIVERSITAS HINDU NEGERI

I GUSTI BAGUS SUGRIWA DENPASAR

VOLUNE 12 NOMOR 1, MARET 2021

\title{
MENDALAMI KONSEPSI KETUHANAN DAN JIWA DALAM KITAB ITIHASA
}

\author{
I Made Putra Aryana ${ }^{1}$, Putu Eddy Purnomo Arta², Ni Kadek Supadmini³, \\ Kadek Jayanthi Riva Prathiwi ${ }^{4}$ \\ 1,2,3,4Universitas Hindu Negeri I Gusti Bagus Sugriwa Denpasar \\ 1madeputra84@gmail.com
}

Keywords: divinity; Itihasa; soul

\section{Kata kunci:}

Itihasa;

Ketuhanan; jiwa
Abstract (Justify, Italic and Bold, book antiqua 11)

This article aims to find out the basics of Hindu teachings contained in the book Itihasa. The Hindu teachings include the concept of divinity and the concept of the soul, because in Itihasa these teachings are implicit in the behavior of everyday life. This article is written using the library method and in-depth study of the literature.Itihassa is Hindu literature that tells the story of the heroism of Hindu knights in the past and is peppered with religious philosophies, mythology, and supernatural beings. Itihasa means this has happened so.Itihasa consists of two epics, namely Ramayana which consists of seven parts and Mahabarata which consists of 18 parts. The concept of Divinity in the Ramayana book mentions many gods, but is categorized as monotysm because they believe in one God who is supreme among all the god. Divinity in the Mahabharata is closely related to Divine knowledge in the Upanisad, Pancasikha, Samkya, Yoga, Pancaratra, Vaisesika, and Vedanta. Jiwa or Atman in Itihasa is the deepest manifestation of each person. The soul is causeless and unchanging.

Abstrak (rata kanan kiri, cetak miring dan tebal, book antiqua 11)

Artikel ini bertujuan untuk mengetahui dasar-dasar ajaran Hindu yang terkandung dalam kitab Itihasa. Ajaran Hindu tersebut antara lain konsep Ketuhanan dan konsep Jiwa, karena dalam Itihasa ajaran tersebut tersirat dalam prilaku hidup sehari-hari. Penulisan artikel ini menggunakan metode kepustakan dan studi mendalam terhadap pustaka. Itihāsa adalah kesusastraan Hindu yang menceritakan kisah kepahlawanan ksatria Hindu pada masa lampau dan dibumbui oleh filsafat agama, mitologi, dan makhluk supernatural. Itihasa artinya ini sudah terjadi begitu. Itihasa terdiri dari dua epos yaitu Ramayana yang terdiri dari tujuh bagian dan Mahabarata 
yang terdiri dari 18 bagian. Konsep Ketuhanan dalam kitab Ramayana menyebut banyak dewa, tetapi dikatagorikan monotysme karena percaya pada satu Tuhan Yang Maha Esa yang tertinggi diantara semua dewa. Ketuhanan dalam Mahabharata berkaitan erat dengan pengetahuan Ketuhanan dalam kitab Upanisad, Pancasikha, Samkya, Yoga, Pancaratra, Vaisesika, dan Vedanta. Jiwa atau Atman dalam Itihasa adalah nyata yang terdalam dari setiap pribadi. Jiwa adalah tanpa sebab dan tidak berubah.

\section{PENDAHULUAN}

Itihāsa adalah suatu bagian dari kesusastraan Hindu yang menceritakan kisahkisah epik/kepahlawanan para Raja dan ksatria Hindu pada masa lampau dan dibumbui oleh filsafat agama, mitologi, dan makhluk supernatural. Itihāsa berarti "kejadian yang nyata". Itihāsa yang terkenal ada dua, yaitu Ramayana dan Mahābhārata Tim Penyusun, 2012: 11).

Kitab Itihāsa disusun oleh para Rsi dan pujangga India masa lampau, seperti misalnya Rsi Walmiki dan Rsi Vyāsa. Cerita dalam kitab Itihāsa tersebar di seluruh daratan India sampai ke wilayah Asia Tenggara. Itīhāsa merupakan Kitab yang tergolong Smerti pada bagian Upaweda. Kata Itihasa berasal dari 3 bagian yaitu iti + ha + asa (iti = begini, $h a=$ tentu, $a s a=$ sudah terjadi) jadi kata Itihas $a$ artinya ini sudah terjadi begitu (Tim penyusun: 2012:11). Namun dalam perkembangan yang terjadi sampai saat ini khususnya di India kata Itihasa sering dihubungkan sebagai Sejarah. Sehingga Itihasa adalah cerita berdasarkan latar sejarah yang memasukkan nilai-nilai ajaran Weda didalamnya.

Itīhāsa sering disebut juga sebagai Wiracarita, karena cerita ini dahulu sering diceritakan melalui tradisi mulut ke mulut. Wiracarita (Wira=Laki, Pahlawan, Berani, Perwira; Carita=cerita) jadi Wiracarita adalah Cerita kepahlawanan. Cerita kepahlawanan ini didasarkan pada latar sejarah para raja, Namun nilai-nilainya tetap diambil dari Weda. Hal tersebut dipertegas dalam Mahabharata pada Svargarohana Parva (5.57) yaitu Parva ke 18.

Itihāsmimaý puóyaý mahàrtaý vedasamitam Vyàsoktaý sruyate yena kåtvà bràhmaóamagrataá

Terjemahannya:

Cerita ini adalah peristiwa sejarah, dan mengandung makna yang dalam, dan mengandung ajaran yang ada pada cerita ini sama seperti ajaran suci Weda. Karya Maharsi Wyasa hendaknya didegar terlebih bagi seorang Brahmana. 
Dari kriteria yang tersebut di atas maka Itihasa atau Wiracarita merupakan salah satu model penjelasan dari Weda yang dilatarkan pada cerita sejarah yang terjadi. Hal tersebut didasarkan atas bukti-bukti sejarah yang menunjukan bahwa tempat kejadian dalam Itihasa masih ada. Contohnya yaitu Kuruksetra medan perang Pandawa dan Kurawa, Jembatan Situbanda penyebrangan Rama ke Alengka dan masih banyak lagi yang lainnya. Namun kandungan makna yang terdapat di dalamnya bisa kita temukan nilai-nilai ajaran Weda.

Itīhāsa sebagai penjelasan lebih disebabkan metode ini lebih bisa dimengerti oleh masyarakat umum melalui cerita sehingga esensi ajaran Weda bisa langsung dipahami dan diterapkan sebagai pedoman hidup, khususnya pembahsan tentang Ketuhanan dan jiwa. Dua Itīhāsa yang sangat terkenal adalah Ramayana dan Mahabarata. Penyusun Kitab Ramayana adalah Maharsi Walmiki sedangkan Kitab Mahabarata disusun oleh Maharsi Wyasa. Kedua Kitab tersebut di atas sangat popular di masyarakat sehingga dalam beberapa kesempatan mendapatkan tempat untuk dibacakan pada saat ada upacara-upacara keagamaan baik sekarang maupun di masa lalu.

Penulisan artikel ini menggunakan analisis data deskriptif kualitatif. Data diperoleh menggunakan metode studi dokumen dan data disajikan secara deskriptif. Dari berbagai sember referensi, dilakukan dianalisa, selanjutkan data disajikan dalam bentuk pemaparan secara kualitatif.

\section{METODE}

Kajian penelitian ini merupakan penelitian kualitatif. Teknik pengumpulan data menggunakan teknik studi kepustakaan dan studi dokumen yang diperoleh melalui pustaka suci Hindu yang lebih khususnya di Itīhāsa. Teknik analisis data menggunakan teknik reduksi data, tahap penyajian data (display) dan tahap penarikan kesimpulan (verifikasi). Hasil dari kajian penelitian ini akan disampaikan dalam bentuk deskriptif atau narasi mendalam yang memenuhi ciri-ciri keilmuan bersifat ilmiah. Bahasa yang digunakan adalah bahasa Indonesia dengan gaya bahasa formal, nalar, obyektif, jelas, tepat dan argumentatif.

\section{PEMBAHASAN}

\section{Konsep Ketuhanan (Brahman) dalam Itihasa}

Konsep Ketuhanan dalam Pandangan Itihasa. Dibagi menjadi dua, pertama dalam pandangan Advaitavedanta (Nirgunabrahman) bahwa Tuhan itu tidak memiliki atribut, 
bentuk, dan rupa. Seperti pada penjelasan dalam Yoga Vasistha, dimana kebenaran hakiki adalah Paramabrahman artinya tidak berbentuk.

Kedua adalah dalam pandangan Dvaitavedanta (Sagunabrahman) bahwa sesungguhnya Tuhan berperibadi, memiliki bentuk dan rupa. Dalam Ramayana, Tuhan dipersonifikasikan sebagai Wisnu yang menjelma menjadi Rama. Dalam Mahabharata, Wisnu memiliki Purusha Awatara dalam wujud Krsihna.

Keduanya merupakan konsep ketuhanan yang tidak dapat dipisahkan satu sama lain, dan saling melengkapi. Wyasa sebagai penulis dari Mahabharata menyatakan "Athato Brahmajnasa" artinya "Segala sesuatu memuncak pada Brahman". Brahman sendiri ada dua pengertian, yakni Saguna dan Nirguna. Saguna adalah Tuhan berwujud dan Nirguna adalah Tuhan yang tidak berwujud.

Pandangan umum mengenai ketuhanan yang terurai dalam kitab suci itihasa, dimana Tuhan dilukiskan sebagai penguasa jiwa, purusa dan prakerti. Tuhan dipandang pula sebagai pengampun atas segala buah dari perbuatan, beliau memberikan kebahagian bagi mereka yang melekukuan perbuatan yang baik dan mengampuni bagi mereka yang berbuat salah. ketuhanan merupakan objek pertama bagi seorang pemeluk agama, apapun namanya. Dalam agama hindu ilmu tentang ketuhanan disebut Brahmavidya yaitu ilmu untuk mempelajari tuhan. Manusia hidup didunia ini adalah suatu proses penyampurnaan diri untuk kembali pada Brahman sebagai awal dan akhir dari kehidupan ini. Untuk dapat dengan mudah kembali kepada tuhan manusia harus mengetahui ciri-ciri sipat Tuhan itu sehingga mudah kembali kepadanya. Agama menuntun manusia untuk mengetahui atau mengidentifikasi tentang tuhan dan ilmu untuk menggetahui tentang tuhan disebut dengan brahmavidya atau theologi. Ketuhanan merupaka suatu yang mendasar yang wajib dipahami oleh penganut agama apapun agamanya.

Untuk dapat memahami pandangan ketuhanan dalam itihasa maka dapat dijelaskan macam-macam keyakinan mengenai ketuhanan yang mana salah satunya merupakan ajaran ketuhanan dalam itihasa itu sendiri, adapun ajaran tersebut sebagai berikut (biakt4.blogspot.com/2013/10/ketuhanan-hindu.html, diakses pada 11 Maret 2021):

1. Animisme adalah keyakinan akan adanya roh dan segala sesuatu yang ada didunia ini didiami oleh roh yang berbeda- beda seperti roh tumbuhan, roh binatang, dan juga roh manusia.

2. Dinamisme adalah suatu keyakinan terhadap adanya kekuatan alam. 
3. Totemisme adalah keyakinan terhadap binatang keramat yang memeiliki kekuatan atau kesaktian.

4. Polytheisme adalah keyakinan terhadap adanya banyak tuhan

5. Natural polytheisme keyakinan terhadap adanya banyak tuhan sebagai penguasa berbagai asfek alam.

6. Henotheisme atau kathenoisme dalah keyakinan terhadap adanya dewa tertinggi (dewata) yang pada masa tertentu digantikan oleh dewa yang lain.

7. Pantheisme adalah keyakinan dimanan mana serba tuhan atau setiap asfek alam digambarkan dikuasai oleh tuhan.

8. Monotheisme adalah keyakinan terhadap adanya tuhan yang maha esa (tuhan yang satu).

9. Monisme adalah keyakinan terhadap adanya keesaan tuhan yang maha esa merupakan hakekat alam samesta.

Ajaran ketuhanan dalam itihasa ini dapat kita jumpai dalam kitab-kitab itihasa baik itu Mahabharata dan Ramayana. Adapun kitab tersebut adalah sebagai berikut;

\section{Mahabharata}

Ketuhanan yang terdapat dalam kitab Mahabharata ini berkaitan erat dengan pengetahuan ketuhanan yang tertulis dalam kitab upanisad, pancasikha, samkya, yoga, pancaratra, vaisesika, dan Vedanta. Namun yang paling banyak mempengaruhi adalah ajaran ketuhanan yang terdapat dalam kitab samkya.

\section{Ramayana}

Bila kita mengkaji lebih jauh tentang ajaran Sradha, khususnya keyakinan kepada Tuhan Yang Maha Esa, sejak proses penyusunan sampai dengan bagian akhir kitab Ramayana, karya Maharsi Valmiki ini menunjukan pemujaan kepada dewa-dewa Trimurti.

Seperti di suratkan oleh Maharsi Valmiki, pemujaan kepada dewa-dewa Trimurti berasal dari masa yang amat tua. Berbagai mantram di dalam kitab suci Rgveda secara terpisah menunjukan pemujaan kepada Kekuatan Tertinggi (Supreme Power) seperti Brahma, Visnu, atau Siva yang merupakan bentuk satu segi tiga, namun di balik yang tiga itu sesungguhnya satu seperti di sebutkan oleh beberapa mantram Veda tentang keesaan Tuhan Yang Maha Agung yang menampilkan Tuhan Yang Maha Esa dalam wujud dan nama-nama yang berbeda-beda (Rgveda I.64.46) 
Seperti halnya pemujaan kepada Tuhan Yang Maha Esa di dalam kitab-kitab Purana, maka di dalam kitab-kitab Itihasa ( Ramayana dan Mahabharata) yang sangat penting dan dominan dipuja adalah Dewa Brahma, Wisnu, Siwa, Ganesa, Laksmi, dan Parvati. Demikian pula pemujaan kepada Dewa Surya, Agni, dan lain-lain yang beasal dari zaman Veda masih berlanjut pada kitab-kitab Itihasa. (Roychoudary, 1983:69)

Kitab Itīhāsa terdiri atas dua buah kitab besar yaitu Ramayana dan Mahabarata. Ramayana karya Maharsi Walmiki terdiri dari 7 Kanda dengan 24.000 sloka. Ramayana berarti kisah perjalanan Sri Rama. Ramayana dibagi menjadi tujuh kitab atau kanda sebagai berikut:

1. Balakanda, Kitab Balakanda merupakan awal dari kisah Ramayana. Kitab Balakanda menceritakan Prabu Dasarata yang memiliki tiga permaisuri, yaitu: Kosalya, Kekayi, dan Sumitra. Prabu Dasarata berputra empat orang, yaitu: Rama, Bharata, Lakshmana dan Satrughna. Kitab Balakanda juga menceritakan kisah Sang Rama yang berhasil memenangkan sayembara dan memperistri Sita, puteri Prabu Janaka.

2. Ayodhyakanda, Kitab Ayodhyakanda berisi kisah dibuangnya Rama ke hutan bersama Dewi Sita dan Lakshmana karena permohonan Dewi Kekayi. Setelah itu, Prabu Dasarata yang sudah tua wafat. Bharata tidak ingin dinobatkan menjadi Raja, kemudian ia menyusul Rama. Rama menolak untuk kembali ke kerajaan. Akhirnya Bharata memerintah kerajaan atas nama Sang Rama.

3. Aranyakanda, Kitab Aranyakakanda menceritakan kisah Rama, Sita, dan Lakshmana di tengah hutan selama masa pengasingan. Di tengah hutan, Rama sering membantu para pertapa yang diganggu oleh para rakshasa. Kitab Aranyakakanda juga menceritakan kisah Sita diculik Rawana dan pertarungan antara Jatayu dengan Rawana.

4. Kiskindhakanda, Kitab Kiskindhakanda menceritakan kisah pertemuan Sang Rama dengan Raja kera Sugriwa. Sang Rama membantu Sugriwa merebut kerajaannya dari Subali, kakaknya. Dalam pertempuran, Subali terbunuh. Sugriwa menjadi Raja di Kiskindha. Kemudian Sang Rama dan Sugriwa bersekutu untuk menggempur Kerajaan Alengka.

5. Sundarakanda, Kitab Sundarakanda menceritakan kisah tentara Kiskindha yang membangun jembatan Situbanda yang menghubungkan India dengan Alengka. Hanuman yang menjadi duta Sang Rama pergi ke Alengka dan menghadap 
Dewi Sita. Di sana ia ditangkap namun dapat meloloskan diri dan membakar ibukota Alengka.

6. Yuddhakanda, Kitab Yuddhakanda menceritakan kisah pertempuran antara laskar kera Sang Rama dengan pasukan rakshasa Sang Rawana. Cerita diawali dengan usaha pasukan Sang Rama yang berhasil menyeberangi lautan dan mencapai Alengka. Sementara itu Wibisana diusir oleh Rawana karena terlalu banyak memberi nasihat. Dalam pertempuran, Rawana gugur di tangan Rama oleh senjata panah sakti. Sang Rama pulang dengan selamat ke Ayodhya bersama Dewi Sita.

7. Uttarakanda, Kitab Uttarakanda menceritakan kisah pembuangan Dewi Sita karena Sang Rama mendengar desas-desus dari rakyat yang sangsi dengan kesucian Dewi Sita. Kemudian Dewi Sita tinggal di pertapaan Rsi Walmiki dan melahirkan Kusa dan Lawa. Kusa dan Lawa ating ke istana Sang Rama pada saat upacara Aswamedha. Pada saat itulah mereka menyanyikan Ramayana yang digubah oleh Rsi Walmiki.

Demikian jumlah sloka Ramayana menakati 24.000 buah namun dalam setiap edisi jumlah slokanya mungkin berbeda dikarenakan terdapat beberapa versi berbeda. Sedangkan di Indonesia Ramayana dikenal melalui Kekawin yang penulisnya tidak dikenal secara pasti namun terdapat nama Yogiswara dalam tulisan akhirnya.

Ketuhanan dalam Ramayana bersangkut paut dengan dengan ketuhanan yang berada dalam kitab suci veda, vedangga, purana, dan Vedanta. Adapun dewa-dewa yang sering di puja dalam Ramayana antara lain Dewa Indra, Dewa Waruna, Dewa Aditya, Dewa Brahma, Dewa Wisnu, Dewa Rudra, Visvasvat, Marut, Soma, Savita, Prajapati, Yama, Uma, Laksmi, Saraswati, Kartikaya, Narayana, Wasudewa, Kuwera, Dartha, Gayatri, dan Skanda. Adanya nama banyak dewa dalam kitab Ramayana ini bukan berarti ketuhanan dalam Ramayana polytisme, namun ketuhanan dalam Ramayana adalah dikatagorikan dalam monotysme, dimana dalam system ketuhananya mereka percaya pada adanya satu Tuhan Yang Maha Esa yang merupakan tuhan yang tertinggi diantara semua dewa.

Kitab Mahabarata berasal dari kata Maha berarti besar dan Bharata berarti rajaraja dari dinasti Bharata. Jadi Mahabharata adalah cerita agung dari keluarga Bharata. Rangkaian kitab menceritakan kronologi peristiwa dalam kisah Mahābhārata, yakni semenjak kisah para leluhur Pandawa dan Korawa (Yayati, Yadu, Puru, Kuru, Duswanta, Sakuntala, Bharata) sampai kisah diterimanya Pandawa di surga. 
1. Adiparwa, Kitab Adiparwa berisi berbagai cerita yang bernafaskan Hindu, seperti misalnya kisah pemutaran Mandaragiri, kisah Bagawan Dhomya yang menguji ketiga muridnya, kisah para leluhur Pandawa dan Korawa, kisah kelahiran Rsi Byasa, kisah masa kanak-kanak Pandawa dan Korawa, kisah tewasnya rakshasa Hidimba di tangan Bhimasena, dan kisah Arjuna mendapatkan Dropadi.

2. Sabhaparwa, Kitab Sabhaparwa berisi kisah pertemuan Pandawa dan Korawa di sebuah balairung untuk main judi, atas rencana Duryodana. Karena usaha licik Sangkuni, permainan dimenangkan selama dua kali oleh Korawa sehingga sesuai perjanjian, Pandawa harus mengasingkan diri ke hutan selama 12 tahun dan setelah itu melalui masa penyamaran selama 1 tahun.

3. Wanaparwa, Kitab Wanaparwa berisi kisah Pandawa selama masa 12 tahun pengasingan diri di hutan. Dalam kitab tersebut juga diceritakan kisah Arjuna yang bertapa di gunung Himalaya untuk memperoleh senjata sakti. Kisah Arjuna tersebut menjadi bahan cerita Arjunawiwaha.

4. Wirataparwa, Kitab Wirataparwa berisi kisah masa satu tahun penyamaran Pandawa di Kerajaan Wirata setelah mengalami pengasingan selama 12 tahun. Yudistira menyamar sebagai ahli agama, Bhima sebagai juru masak, Arjuna sebagai guru tari, Nakula sebagai penjinak kuda, Sahadewa sebagai pengembala, dan Dropadi sebagai penata rias.

5. Udyogaparwa, Kitab Udyogaparwa berisi kisah tentang persiapan perang keluarga Bharata (Bharatayuddha). Kresna yang bertindak sebagai juru damai gagal merundingkan perdamaian dengan Korawa. Pandawa dan Korawa mencari sekutu sebanyak-banyaknya di penjuru Bharatawarsha, dan hampir seluruh Kerajaan India Kuno terbagi menjadi dua kelompok.

6. Bhismaparwa, Kitab Bhismaparwa merupakan kitab awal yang menceritakan tentang pertempuran di Kurukshetra. Dalam beberapa bagiannya terselip suatu percakapan suci antara Kresna dan Arjuna menjelang perang berlangsung. Percakapan tersebut dikenal sebagai kitab Bhagavad Gītā. Dalam kitab Bhismaparwa juga diceritakan gugurnya Resi Bhisma pada hari kesepuluh karena usaha Arjuna yang dibantu oleh Srikandi.

7. Dronaparwa, Kitab Dronaparwa menceritakan kisah pengangkatan Bagawan Drona sebagai panglima perang Korawa. Drona berusaha menangkap Yudistira, namun gagal. Drona gugur di medan perang karena dipenggal oleh Drestadyumna ketika ia sedang tertunduk lemas mendengar kabar yang menceritakan kematian anaknya, 
Aswatama. Dalam kitab tersebut juga diceritakan kisah gugurnya Abimanyu dan Gatotkaca.

8. Karnaparwa, Kitab Karnaparwa menceritakan kisah pengangkatan Karna sebagai panglima perang oleh Duryodana setelah gugurnya Bhisma, Drona, dan sekutunya yang lain. Dalam kitab tersebut diceritakan gugurnya Dursasana oleh Bhima. Salya menjadi kusir kereta Karna, kemudian terjadi pertengkaran antara mereka. Akhirnya, Karna gugur di tangan Arjuna dengan senjata Pasupati pada hari ke-17.

9. Salyaparwa, Kitab Salyaparwa berisi kisah pengangkatan Sang Salya sebagai panglima perang Korawa pada hari ke-18. Pada hari itu juga, Salya gugur di medan perang. Setelah ditinggal sekutu dan saudaranya, Duryodana menyesali perbuatannya dan hendak menghentikan pertikaian dengan para Pandawa. Hal itu menjadi ejekan para Pandawa sehingga Duryodana terpancing untuk berkelahi dengan Bhima. Dalam perkelahian tersebut, Duryodana gugur, tapi ia sempat mengangkat Aswatama sebagai panglima.

10. Sauptikaparwa, Kitab Sauptikaparwa berisi kisah pembalasan dendam Aswatama kepada tentara Pandawa. Pada malam hari, ia bersama Kripa dan Kertawarma menyusup ke dalam kemah pasukan Pandawa dan membunuh banyak orang, kecuali para Pandawa. Setelah itu ia melarikan diri ke pertapaan Byasa. Keesokan harinya ia disusul oleh Pandawa dan terjadi perkelahian antara Aswatama dengan Arjuna. Byasa dan Kresna dapat menyelesaikan permasalahan itu. Akhirnya Aswatama menyesali perbuatannya dan menjadi pertapa.

11. Striparwa, Kitab Striparwa berisi kisah ratap tangis kaum wanita yang ditinggal oleh suami mereka di medan pertempuran. Yudistira menyelenggarakan upacara pembakaran jenazah bagi mereka yang gugur dan mempersembahkan air suci kepada leluhur. Pada hari itu pula Dewi Kunti menceritakan kelahiran Karna yang menjadi rahasia pribadinya.

12. Santiparwa, Kitab Santiparwa berisi kisah pertikaian batin Yudistira karena telah membunuh saudara-saudaranya di medan pertempuran. Akhirnya ia diberi wejangan suci oleh Rsi Byasa dan Sri Kresna. Mereka menjelaskan rahasia dan tujuan ajaran Hindu agar Yudistira dapat melaksanakan kewajibannya sebagai Raja.

13. Anusasanaparwa, Kitab Anusasanaparwa berisi kisah penyerahan diri Yudistira kepada Resi Bhisma untuk menerima ajarannya. Bhisma mengajarkan tentang ajaran Dharma, Artha, aturan tentang berbagai upacara, kewajiban seorang Raja, dan sebagainya. Akhirnya, Bhisma meninggalkan dunia dengan tenang. 
14. Aswamedhikaparwa, Kitab Aswamedhikaparwa berisi kisah pelaksanaan upacara Aswamedha oleh Raja Yudistira. Kitab tersebut juga menceritakan kisah pertempuran Arjuna dengan para Raja di dunia, kisah kelahiran Parikesit yang semula tewas dalam kandungan karena senjata sakti Aswatama, namun dihidupkan kembali oleh Sri Kresna.

15. Asramawasikaparwa, Kitab Asramawasikaparwa berisi kisah kepergian Drestarastra, Gandari, Kunti, Widura, dan Sanjaya ke tengah hutan, untuk meninggalkan dunia ramai. Mereka menyerahkan tahta sepenuhnya kepada Yudistira. Akhirnya Resi Narada datang membawa kabar bahwa mereka telah pergi ke surga karena dibakar oleh api sucinya sendiri.

16. Mosalaparwa, Kitab Mosalaparwa menceritakan kemusnahan bangsa Wresni. Sri Kresna meninggalkan kerajaannya lalu pergi ke tengah hutan. Arjuna mengunjungi Dwarawati dan mendapati bahwa kota tersebut telah kosong. Atas nasihat Rsi Byasa, Pandawa dan Dropadi menempuh hidup “sanyasin” atau mengasingkan diri dan meninggalkan dunia fana.

17. Mahaprastanikaparwa, Kitab Mahaprastanikaparwa menceritakan kisah perjalanan Pandawa dan Dropadi ke puncak gunung Himalaya, sementara tahta kerajaan diserahkan kepada Parikesit, cucu Arjuna. Dalam pengembaraannya, Dropadi dan para Pandawa (kecuali Yudistira), meninggal dalam perjalanan.

18. Swargarohanaparwa, Kitab Swargarohanaparwa menceritakan kisah Yudistira yang mencapai puncak gunung Himalaya dan dijemput untuk mencapai surga oleh Dewa Indra. Dalam perjalanannya, ia ditemani oleh seekor anjing yang sangat setia. Ia menolak masuk surga jika disuruh meninggalkan anjingnya sendirian. Si anjing menampakkan wujudnya yang sebenanrnya, yaitu Dewa Dharma.

Ketuhanan yang terdapat dalam kitab Mahabarata berkaitan erat dengan pengetahuan ketuhanan yang tertulis dalam kitab Upanisad, Pancasikha, Samkya, Yoga, Pancaratra, Veisesika dan Vedanta. Ajaran ketuhanan yang paling banyak mempengaruhi adalah ajaran ketuhanan yang terdapat dalam kitab Samkya.

\section{Konsep Roh/Jiwa (Atman) dalam Itihasa}

Pengertian roh menurut Hindu jiwa adalah sebuah prinsip kehidupan biologis, kepakaan perasaan dan gerakan, sedang roh sangat berbeda dengan jiwa dalam konteks bahwa roh diwujudkan dengan tidak normal roh bersifat aktif merupakan kekuatan supernatural yang bebas jarak,seringkali terbang dan hampir selalu sibuk, selalu 
mengirimkan pesan-pesan, selalu memicu masalah, selalu banyak membantu,selalu mengusik dan juga selalu menyiksa. Percaya pada roh-roh merupakan keyakinan semua, atau hampir semua umat manusia biasanya (roh) adalah pancaran (emanasi) dari subtansi Tuhan sehingga ia dapat hidup tanpa badan dan kekal artinya tidak mati. Dalam agama Hindu roh disebut atman (jiwa).atman atau atma yaitu hidupnya hidup dari manusia asalnya adalah dari tuhan atman (brahman). Atman merupakan percikan kecil dari brahman yang tertinggi. Atman yang menghidup badan disebut jiwatman (nyawa). Dalam filsafat bagian yang menguraikan tentang ini disebut atma tattwa.

aham atma gudakedasarwabhutasyasthitahaham adis ca madhyam cabhutanam anta eva ca (bhagawad gita $x .20$ )

artinya:"o,arjuna, aku adalah atma menetap dalam hati semua makhlukaku adalah permulaan, pertengahandan akhir dari pada semua makhluk.

Dari kutipan ini dapat kita mengerti bahwa sesungguhnya bagian dari tuhanlah atma itu. Bila kita andaikan Tuhan sebagai lautan maka atma itu hanyalah setitik embun dari uap airnya. Demikianlah Tuhan asal atma sehingga ia diberi gelar paramatma yaitu atma yang tertinggi. Atman merupakan yang nyata yang terdalam dari setiap pribadi. Dia adalah tanpa sebab dan tidak berubah, ketika mengetahui dirinya sebagai jiwa dan berhenti mengerti dirinya sebagai terikat oleh nama maupun bentuk (nama-rupa) dia sebenarnya menyadari sifatnya yang sesungguhnya. Jiwa dalam Mahabharata lebih banyak diuraikan pada bagian Bhisma Parwa, yang tertuang pada Bhagavadgita. Atman mempunyai sifat-sifat seperti yang tersebut dalam kitab bhagawadgita 11.20.23.24.

na jayate mriyate wa kadacin na'yam bhutwana bhiyah aja nityah saswato yam purano na hanyate hanyamane sarire. (bhagawadgita 11.20)

Ia tidak pernah lahir dan juga tidak pernah mati kapanpun juga tak pernah muncul dan tidak lagi pernah menghilangia adalah tidak mengenal kelahiran, kekal abadi dan selalu ada.ia tak dapat dibunuh bila badan.

nai;nam chindanti sastrani nai nam dahati pewakah na cai'nam kledayanty apa na sosayati marutah. (bhagawadgita 11.24) (bhagawadgita 11.23)

senjata tidak dapat memotong jiwatma api tidak dapat membakarnya air tidak dapat membasahinya pun angin tak dapat mengeringkan

cchedyo yam adahyo yam akledyo sasya eva ca nutyah sarwagatah sthamun acalo yam samatanah (bhagawadgita 11.14)

ia tidak dapat dipotong, tidak dapat dibakar ia tidak dapat dibasahi,maupun dikeringkan ia adalah abadi, berada dimana-mana tidak berubah dan bergerak, ia adalah selalu sama.

awyakto yamacintyo yam awikaryo yam ecyate tasmad ewam widiwai nam na' nusocitum arhasi(bhagawadgita 11.25) 
ia dikatakan tidak berwujud, tidak terpikirkan, tidak berubah-ubah, oleh karena itu mengetahui ia demikian engkau seharusnya tidak bersedih hatijadi sifat-sifat atma itu meliputi:

acchedya=tak terlukai oleh senjata

adahya $=$ tak terbakar

akledya $=$ tak terkeringkan

asesyah $=$ tak terbasahkan

nitya $=$ abadi

sarwagaTah=ada dimana-mana

stahanu =tak terpindah-pindah

acala $=$ tak bergerak

sanatama $=$ selalu sama

awyakta $=$ tak dilahirkan

acchintya=tak terfikirkan

awikara $=$ tak berobah

\section{PENUTUP}

Itihasa disebut juga wiracarita atau epos memuat berbagai aspek pemikiran keagamaan. Hubungan itihasa dengan dengan kitab suci Veda yaitu Veda adalah wahyu Tuhan Yang Maha Esa sebagai sumber tertinggi ajaran agama Hindu, sedang kitab-kitab Itihasa memberi penjelasanyang terang tentang implementasi ajaran suci Veda dalam kehidupan sehari-hari. Itihasa terdiri dari Ramayana karya Valmiki dan Mahabarata karya Maharsi Vyasa. Baik Ramayana maupun Mahabarata disebut Arsakavya, yakni karya sastra yang membahagiakan pembaca dan pendengarnya. Ramayana terdiri dari Sapta kanda, yakni tujuh buah buku. Kitab Mahabarata terdiri dari delapan belas parwa, oleh karena itu disebut juga Astadasaparva, di dalamnya terdapat Bhagavadgita. Ajaran yang terkandung dalam Itihasa meliputi semua aspek kehidupan, ajaran agama, moralitas, social, politi dan budaya. Ajaran agama Hindu dalam Itihasa meliputi konsep ketuhanan, konsep jiwa dan konsep kelepasan atau moksa.

Ketuhanan dalam Ramayana bersangkut paut dengan dengan ketuhanan yang berada dalam kitab suci veda, vedangga, purana, dan Vedanta. Adanya nama banyak dewa dalam kitab Ramayana ini bukan berarti ketuhanan dalam Ramayana polytisme, ketuhanan dalam Ramayana dikatagorikan monotysme, dimana dalam system ketuhananya, percaya pada adanya satu Tuhan Yang Maha Esa yang merupakan Tuhan yang tertinggi diantara semua dewa. Ajaran ketuhanan dalam Mahabharata banyak dipengaruhi oleh ajaran ketuhanan yang terdapat dalam kitab Samkya.

Sesungguhnya bagian dari Tuhanlah atma itu. Bila kita andaikan Tuhan sebagai lautan maka atma itu hanyalah setitik embun dari uap airnya. Demikianlah Tuhan asal 
atma sehingga ia diberi gelar paramatma yaitu atma yang tertinggi. Atman merupakan yang nyata yang terdalam dari setiap pribadi.

\section{DAFTAR PUSTAKA}

Nurkancana, Wayan. 2010. Keutamaan Maha Bharata. Denpasar: Pustaka Menikgeni.

Pandit, Bansi. 2003. Pemikiran Hindu: Pokok-Pokok Pemikiran Hindu dan Filsafatnya. Surabaya: Paramita.

Pudja, G. 1999. Bhagavad Gita (Pancamo Veda). Surabaya: Paramita.

Rajagopalachari, S. 2013. Mahabharata. Jogjakarta: IRCiSoD

Subramaniam, Kamala. 2001. Ramayana. Surabaya: Paramita.

Tim Penyusun. 2012. Dasar-Dasar Agama Hindu. Jakarta: Direktorat Jendral Bimbingan Masyarakat Hindu Kementerian Agama RI.

Tim Penyusun. 2012. Itihasa. Jakarta: Direktorat Jendral Bimbingan Masyarakat Hindu Kementerian Agama RI.

Titib, I Made. 1996. Veda Sabda Suci Pedoman Praktis Kehidupan. Surabaya Paramita. http://biakt4.blogspot.com/2013/10/ketuhanan-hindu.html, diakses pada 11 Maret 2021. 